\title{
Productivity of grain of early hybrids of corn of different strain changings
}

\author{
B. Dziubetskyi, \\ Academician of the National Academy of Agricultural Sciences of Ukraine, \\ Doctor of Agricultural Sciences \\ V. Cherchel, \\ Candidate of Agricultural Sciences \\ State Institution Institute of Grain Crops of the National Academy of Agricultural Sciences of \\ Ukraine
}

The purpose. To determine advance of productivity of early hybrids of corn FAO $150-240$ of different strain changings of selection of corn of SE Institute of grain crops of NAAS. Methods. Hybridization, inbreeding, cumulative selection — during creation of initial material and hybrids; visual for phenological observations; measuring-weight - for record-keeping the yield; mathematical-andstatistical - for determination of reliability of results. Results. For the last 28 years $(1987-2015) \mathrm{SE}$ IGC of NAAS has registered in Ukraine 34 early hybrids FAO $150-240$ which may be timephased on 4 strain changings. Each next of them has the increase yield of grain of new genotypes. Its general increase makes $3,46 \mathrm{t} /$ hectare, and lowering of harvest damp of grain $-4,5 \%$. With the purpose of determination of genetic component in productivity of grain of early samples comparison of hybrids is carried out: hybrid-standard of the first strain changing Dneprovskii $203 \mathrm{MV}$, connecting second and third strain changings Dneprovskii 181 SV and the best sample of the last strain changing DN - Garant. It is determined that annual increase of productivity of grain of early hybrids for 28 years has made 0,08 t/hectare. Conclusions. The stateof- the-art world trend of varietal policy in production of corn is founded on increase of prevalence of a share of early hybrids in assortment of different biotypes of this crop. Spread of early genotypes in conditions of Steppe is connected to development of resources-saving techniques in plant growing and advance in selection of early samples of South ecotype.

Key words: corn, selection, hybrid, early growth, strain changing, productivity of grain.

Selection of corn on heterosis is the main task of the breeder, who consciously or unconscious selects the fruitful combinations. The greatest progress in increase of grain yield of corn was observed with the introduction in selection of heterosis effect. Thanks to the hybrid genotype the average grain yield in the United States for the period 1930-1980 years increased by 1 centner / ha per year [1], and M.I. Khadzhynov recorded that the average annual increase of grain yild from 1946 to 1976 in hybrids by comparison with variety Sterling was $0.85 \mathrm{~kg} /$ ha [2]. The research in Germany has shown that progress in corn selection in the period from 1939 to 2001 gave the annual increase of grain yield by $2.3 \mathrm{~kg} / \mathrm{ha}$ [3]. For the last forty years of the twentieth century, the average grain yield of corn in the world increased annually by $61 \mathrm{~kg} / \mathrm{ha}$ [4], while the selective increase component was $80 \%$ [5].

Some scientists believe that the potential grain yield which can be achieved by conventional selection way have nearly exhausted in modern hybrids [6,7]. Relevant doubts are refuted by the National Association of Maize Production, which annually arranges the competition concerning of growing of hybrids in optimal conditions, where set new records of grain yield. In particular, in 2015 it was received $33.4 \mathrm{t} /$ ha of grain in Virginia (USA), the new world record of grain yield of corn [8].

However, an attention to obtaining of potential grain yield in corn selection is reduced and further greater importance assume the factors that provide convenience and high economic indicators of production [6,9]. The level of grain yield of corn hybrids and its stability depend heavily from extreme 
environmental factors. The use of early- ripening corn hybrids is the important factor for the confrontation to stress factors in the Steppe of Ukraine during the corn grain production. Successful realization of this strategy is possible only with the availability of early- ripening hybrids of southern ecotypes.

Goal of research - the determination of progress in the productivity of early- ripening corn hybrids (FAO 150-240) selection of the State Institution Institute of Grain Crops of the NAAS in different strain changing.

Materials and methods. The research was conducted in the course of 1994-2015 years in the selection crop rotation with competitive strain testing of hybrids at Governmental Enterprise Pilot Farm "Dnipro". Area of trial plots was $10 \mathrm{~m}^{2}$, replication of test - three times. The sowing was conducted with special selection drill at the end of the third decade of April. Density of stand was 60 thousands plants/hectare. Harvesting took place in the second half of September with application of selective combine "Wintershtager" by simultaneous definition of yield and grain moisture using a computer.

The parental material consisted of early- ripening hybrids FAO 150-240 listed in the State

Register of Plant Varieties suitable for distribution in Ukraine. Statistical data processing was carried out by standard methods $[10,11]$.

Results of research. The duration of our observations allows to trace some strain changing of early- ripening hybrids of selection of SI IGC NAAS of Ukraine (Table 1).

1. Characteristics of early ripening corn hybrids from different years of registration by productivity during 1994-2015 years of research

\begin{tabular}{|l|l|l|l|l|l|l|l|}
\hline \multirow{2}{*}{ No } & \multirow{2}{*}{$\begin{array}{l}\text { Name of hybrid } \\
\text { tion year }\end{array}$} & Registra- & \multicolumn{2}{|l|}{ Average } & \multirow{2}{*}{3} & \multicolumn{2}{l}{ Limits } \\
& & 1987 & 4.16 & 19.1 & 9 & 1.83 & 5.83 \\
\hline 1 & Dniprovskyi 203MV & 1994 & 4.07 & 18.8 & 9 & 2.55 & 5.57 \\
\hline 3 & Luch 170 MV & 1996 & 3.90 & 16.8 & 10 & 1.67 & 5.26 \\
\hline 4 & Dniprovskyi 145 MB & 1996 & 4.27 & 19.9 & 8 & 2.56 & 5.51 \\
\hline 5 & Dniprovskyi 172MB & 1996 & 4.27 & 19.9 & 6 & 2.54 & 5.34 \\
\hline 6 & Dniprovskyi 193MB & 1998 & 4.79 & 19.6 & 7 & 2.62 & 7.29 \\
\hline 7 & Dniprovskyi 187CB & 1998 & 5.09 & 17.2 & 7 & 3.59 & 7.24 \\
\hline 8 & Kadr 195 SV & 2001 & 5.79 & 17.6 & 11 & 4.45 & 8.66 \\
\hline 9 & Kadr 217 MV & 2002 & 5.10 & 16.7 & 9 & 2.57 & 8.81 \\
\hline 10 & Dniprovskyi 181 SV & 2002 & 6.24 & 15.7 & 14 & 4.82 & 9.13 \\
\hline 11 & Dniprovskyi 223 SV & 2002 & 5.43 & 16.2 & 7 & 3.43 & 8.46 \\
\hline 12 & Dniprovskyi 196 SV & 2003 & 5.39 & 16.1 & 9 & 2.92 & 7.85 \\
\hline 13 & Kremin 200 SV & 2003 & 5.80 & 16.5 & 13 & 3.44 & 8.28 \\
\hline 14 & Surskyi 197 MV & 2004 & 5.79 & 16.5 & 3 & 4.15 & 7.35 \\
\hline 15 & Runo 198 SV & 2005 & 5.72 & 15.7 & 8 & 3.62 & 9.15 \\
\hline 16 & Tovtryanskyi 188 SV & 2007 & 6.14 & 15.6 & 7 & 4.05 & 8.49 \\
\hline 17 & Zalishchytskyi 191 SV & 2007 & 6.61 & 16.4 & 7 & 4.43 & 9.31 \\
\hline 18 & Ushchytskyi 167 SV & 2007 & 5.92 & 15.6 & 7 & 4.33 & 7.74 \\
\hline 19 & Virazh 178 MV & 2008 & 6.19 & 15.2 & 5 & 5.08 & 8.65 \\
\hline 20 & Pochaivskyi 190 MV & 2009 & 6.63 & 14.8 & 9 & 5.17 & 9.72 \\
\hline 21 & Izyaslav 220 MV & 2010 & 7.02 & 14.5 & 8 & 5.60 & 9.23 \\
\hline 22 & Orzhytsia 237 MV & 2010 & 7.20 & 14.8 & 8 & 4.94 & 9.78 \\
\hline 23 & Kvitnevyi 187 MV & 2010 & 7.05 & 13.9 & 7 & 5.55 & 8.75 \\
\hline 24 & Yarovets 243 MV & 2010 & 7.18 & 14.2 & 7 & 6.04 & 8.90 \\
\hline 25 & Chumak & 2012 & 7.49 & 12.9 & 4 & 5.91 & 9.79 \\
\hline 26 & Nemyriv & 2012 & 7.50 & 13.3 & 7 & 6.23 & 9.34 \\
\hline 27 & Vizavi & 2013 & 7.76 & 14.9 & 6 & 6.72 & 9.48 \\
\hline & & & & & & & \\
\hline
\end{tabular}




\begin{tabular}{|l|l|l|l|l|l|l|l|}
\hline 28 & Verdykt & 2013 & 6.88 & 14.4 & 9 & 5.18 & 9.56 \\
\hline 29 & DN Pivakha & 2014 & 7.77 & 14.5 & 4 & 6.62 & 9.15 \\
\hline 30 & DN Garant & 2014 & 8.48 & 15.3 & 4 & 7.30 & 9.64 \\
\hline 31 & DN Festling & 2014 & 7.84 & 15.7 & 4 & 6.53 & 8.66 \\
\hline 32 & DN Zlata & 2014 & 8.24 & 14.7 & 4 & 6.99 & 9.46 \\
\hline 33 & DN Palanok & 2015 & 7.86 & 14.2 & 4 & 6.29 & 9.73 \\
\hline 34 & DN Synevyr & 2015 & 6.73 & 14.3 & 6 & 5.08 & 8.99 \\
\hline
\end{tabular}

Note: 1. Grain yield, t / ha; 2. Grain moisture at harvesting, \%; 3. Number of years of testing.

It should be noted that all selection research were conducted in the Northern Steppe zone, where every year there was the water consumption deficit in the soil and air, that makes possible to estimate the progress in formation of drought-resistant of early - ripening hybrids.

During the period from 1987 to the present were registered total 34 early- ripening hybrids. First strain changing included 7 corn hybrids, which were registered during the 1987-1998 years.

This strain changing consisted of double and trilinear hybrids today excluded from the State Register. They average over the test years provided grain yield $4.36 \mathrm{t} /$ ha with the humidity in the harvesting of $18.7 \%$ (Figure 1).

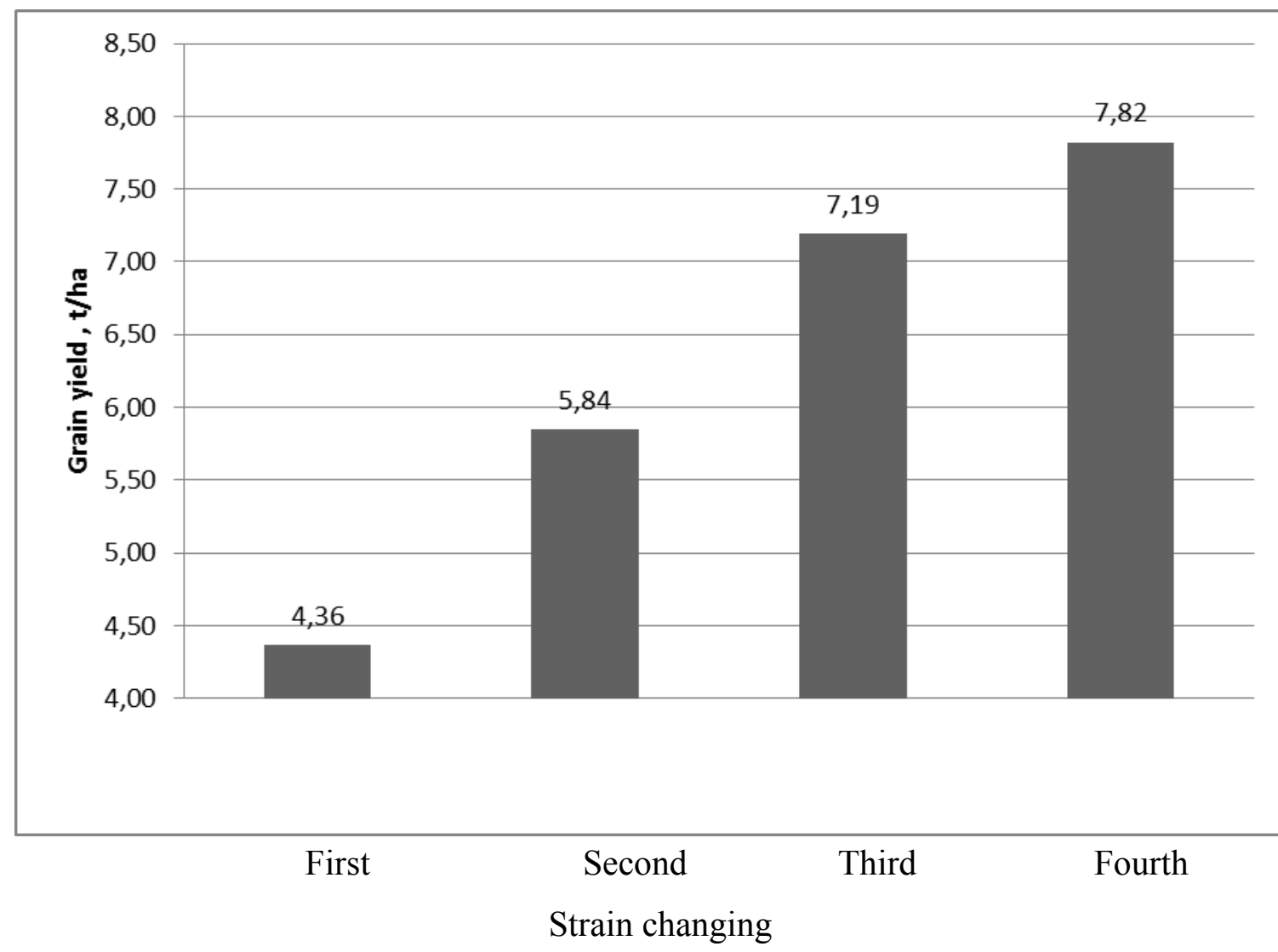

Fig. 1. Progress of grain yield of early - ripening corn hybrids FAO 150-240 on different strain changing

The second strain changing was formed at the period from 2001 to 2008 . It is represented 12 hybrids, of which 8 three-lined and four - simple modified hybrids. These hybrids in an average year tests showed grain yield at level $5.84 \mathrm{t} /$ ha with harvesting moisture content of $16.2 \%$. Among this strain changing 6 corn hybrids remain still in the State Register of Plant Varieties including known: Dniprovskyi 181 SV, Kremin 200 SV, Zalishchytskyi 191 SV but cucle of their industrial use is completed.

The hybrids of the third strain changing registered from 2009 to 2013 on average per year trial had grain yield at level $7.19 \mathrm{t} /$ ha by harvest grain moisture $14.2 \%$. There hybrids are widely used in the 
modern production and consist mainly of simple modified and two simple hybrids: Pochaivskyi $190 \mathrm{MV}$ and Kvitnevyi $187 \mathrm{MV}$.

The fourth strain changing being formed just only and it is introduced into production. During the 2014-2015 years were registered 6 hybrids. Therefore, the advantage of these samples is less in comparison with other cycles and is only $0.63 \mathrm{t} / \mathrm{ha}$, whereas by the second and third strain changing was recorded an increase in grain yield at 1.48 and $1.35 \mathrm{t} /$ ha, respectively.

Marked increase grain yield in early- ripening corn hybrids at level $3.46 \mathrm{t} /$ ha for 21 years of research corresponds to the general trend [12], but its manifestation in more than 3 times larger than the specified average grain yield of hybrids FAO 150-450. Thus, the calculations for periods of five years of research found a continuous increase in grain yield of early ripening group of hybrids over 20 years of research by an average of $1.57 \mathrm{t} /$ ha (Table 2). While regarding other groups of ripening were observed less and uneven growth in grain yield.

2. Mean values of grain yield and grain moisture at harvesting of corn hybrids in accordance with fiveyear period of competitive strain testing

\begin{tabular}{|l|l|l|l|l|l|l|l|l|}
\hline \multirow{3}{*}{ FAO } & \multicolumn{9}{|l|}{ Mean values for the testing periods } \\
\cline { 2 - 9 } & $95-99$ & $00-05$ & $06-10$ & $11-15$ & $95-99$ & $00-05$ & $06-10$ & $11-15$ \\
\cline { 2 - 9 } & Grain yield, t/ha & \multicolumn{3}{|l|}{ Grain moisture at harvesting, \% } \\
\hline $150-190$ & 4.88 & 5.46 & 5.59 & 6.45 & 19.0 & 16.8 & 15.0 & 14.5 \\
\hline $200-290$ & 5.38 & 5.96 & 5.91 & 6.72 & 20.3 & 17.7 & 16.1 & 15.1 \\
\hline $300-390$ & 5.98 & 6.27 & 5.77 & 6.70 & 22.6 & 19.5 & 17.4 & 15.6 \\
\hline$>400$ & 6.20 & 6.65 & 5.72 & 6.65 & 26.0 & 21.0 & 20.2 & 16.5 \\
\hline
\end{tabular}

Note. Testing periods are calculated for five years, 2000-2005. 2004 year is not included in due to roguing of experiment.

Thus, the increase of grain yield of early-ripening corn hybrids was observed in the course of all period of observation. However, along with genetic progress undoubtedly is important the environment component. For the purpose of environment influence separation was made a comparison with hybrid Dniprovskyi 181 SV which had been investigated 14 years in the competitive strain testing. This hybrid combines all strain changing.

The test in 2000-2002 known in due time early - ripening corn hybrids Luch $170 \mathrm{MV}$ and Dniprovskyi 203 MV with a new at that time hybrid Dniprovskyi 181 SV revealed advantage of the last one over all years of the research (Table 3). Especially valuable character of the new hybrid was high grain yield stability in stressful years, so it does not lose popularity today. On average for three years Dniprovskyi $181 \mathrm{SV}$ formed grain yield at level $5.32 \mathrm{t} /$ ha, which was on 1.35 and $1.66 \mathrm{t} /$ ha more than for hybrids Luch 170 MV and Dniprovskyi 203 MV, respectively.

\section{Comparison of early ripening corn hybrids by productivity and grain moisture at harvesting of different strain changing}

\begin{tabular}{|c|c|c|c|c|c|c|c|c|c|}
\hline \multirow{3}{*}{ No } & \multirow{3}{*}{ Name of hybrid } & \multicolumn{8}{|c|}{ Years of research } \\
\hline & & 2000 & 2001 & 2002 & $\bar{x}$ & 2000 & 2001 & 2002 & $\bar{x}$ \\
\hline & & \multicolumn{4}{|c|}{ Grain yield, t/ha } & \multicolumn{4}{|c|}{$\begin{array}{l}\text { Moisture of grain at harvesting, } \\
\%\end{array}$} \\
\hline 1 & Luch $170 \mathrm{MV}$ & 5.57 & 3.77 & 2.59 & 3,98 & 18.8 & 16.1 & 18.5 & 17.8 \\
\hline 2 & Dniprovskyi 203MV & 5.51 & 3.66 & 1.83 & 3,67 & 18.7 & 15.7 & 19.7 & 18.0 \\
\hline 3 & Dniprovskyi 181 SV & 5.98 & 5.17 & 4.82 & 5,32 & 18.4 & 13.8 & 19.1 & 17.1 \\
\hline \multicolumn{2}{|c|}{ Average on the group } & 5.90 & 4.33 & 3.19 & 4,48 & 17.7 & 15.2 & 19.0 & 17.3 \\
\hline
\end{tabular}


The research of the hybrids of third and fourth strain changing in the 2013-2015 years revealed average sustained excess of standard Dniprovskyi $181 \mathrm{SV}$ on grain yield from 0.20 to $1.67 \mathrm{t} / \mathrm{ha}$ (Table 4).

4. Comparison of early-ripening corn hybrids by the productivity and grain moisture at harvesting of different strain changing

\begin{tabular}{|c|c|c|c|c|c|c|c|c|c|}
\hline \multirow{3}{*}{ № } & \multirow{3}{*}{ Name oh hybrid } & \multicolumn{8}{|c|}{ Years of research } \\
\hline & & 2013 & 2014 & 2015 & $\bar{x}$ & 2013 & 2014 & 2015 & $\bar{x}$ \\
\hline & & \multicolumn{4}{|c|}{ Grain yield, t/ha } & \multicolumn{4}{|c|}{$\begin{array}{l}\text { Moisture of grain at harvesting, } \\
\%\end{array}$} \\
\hline 1 & Dniprovskyi 181 SV & 7.25 & 5.93 & 6.11 & 6.43 & 19.9 & 11.5 & 13.4 & 14.9 \\
\hline 2 & Pochaivskyi $190 \mathrm{MV}$ & 7.97 & 5.78 & 6.38 & 6.71 & 17.8 & 11.4 & 12.9 & 14.0 \\
\hline 3 & Izyaslav 220 MV & 7.80 & 6.47 & 6.03 & 6.77 & 18.2 & 11.8 & 13.5 & 14.5 \\
\hline 4 & Orzhytsia $237 \mathrm{MV}$ & 9.00 & 6.64 & 6.56 & 7.40 & 18.5 & 12.6 & 14.0 & 15.0 \\
\hline 5 & Kvitnevyi $187 \mathrm{MV}$ & 7.88 & 6.18 & 6.61 & 6.89 & 17.0 & 11.2 & 12.6 & 13.6 \\
\hline 6 & Yarovets $243 \mathrm{MV}$ & 8.20 & 6.09 & 6.78 & 7.02 & 16.8 & 11.4 & 13.0 & 13.7 \\
\hline 7 & Nemyriv & 8.35 & 7.06 & 6.72 & 7.38 & 17.1 & 11.8 & 12.9 & 14.0 \\
\hline 8 & Vizavi & 9.15 & 6.79 & 6.72 & 7.56 & 18.3 & 12.2 & 13.8 & 14.8 \\
\hline 9 & Verdykt & 8.14 & 6.07 & 7.04 & 7.08 & 17.3 & 11.8 & 14.3 & 14.5 \\
\hline 10 & ZN Cynevyr & 7.78 & 6.02 & 6.08 & 6.63 & 16.7 & 11.9 & 12.9 & 13.8 \\
\hline 11 & ДN Pyvykha & 8.25 & 7.05 & 6.62 & 7.31 & 17.4 & 11.4 & 13.7 & 14.2 \\
\hline 12 & ДN Garant & 9.35 & 7.64 & 7.30 & 8.10 & 18.5 & 13.3 & 13.7 & 15.2 \\
\hline 13 & ZN Palanok & 8.55 & 6.29 & 6.87 & 7.24 & 17.7 & 11.5 & 12.6 & 13.9 \\
\hline 14 & ДN Zlata & 9.00 & 7.51 & 6.99 & 7.83 & 17.7 & 12.1 & 13.8 & 14.5 \\
\hline 15 & ZN Festling & 8.59 & 7.59 & 6.53 & 7.57 & 18.8 & 13.0 & 13.7 & 15.2 \\
\hline \multicolumn{2}{|c|}{ Average on the group } & 8.32 & 6.34 & 6.52. & 7.06 & 18.1 & 12.1 & 13.7 & 14.6 \\
\hline
\end{tabular}

Clearly evident trend of grain yield increase of hybrids was observed in different strain changing. In particular, in the third strain changing the progress of grain yield averaged out $0.67 \mathrm{t} / \mathrm{ha}$, and the fourth $1.02 \mathrm{t} /$ ha. Hybrid Dniprovskyi 181SV has left from the top - 10 and the last time it grain yield was less than the average grain yield of early- ripening hybrids for the competitive strain testing.

The comparison of the three-year research 2000-2002 and 2013-2015 years revealed the increase of the grain yield of hybrid Dniprovskyi $181 \mathrm{SV}$ on $1.11 \mathrm{t} /$ ha in the last period of research, which can be regarded as component of the environment. In accordance with the comparison of the results obtained with the hybrid of first strain changing Dniprovskyi 203 MV and better hybrid of fourth strain changing DN Garant it was determined that for 28 years of selection of early- ripening hybrids in SI IGC NAAS of Ukraine the progress was $3.33 \mathrm{t} / \mathrm{ha}$, and with regard for the environmental impact at level $2.22 \mathrm{t} / \mathrm{ha}$. That annual increase of the genetic component in the selection of early - ripening hybrids of institution was $0.08 \mathrm{t} / \mathrm{ha}$.

\section{Conclusions.}

As the result of long-term years of research was not only the improvement and development of methods for identification and selection of drought resistant genotypes, the extension of general ideas about plant resistance to drought, but also formation of valuable early- ripening parental material of southern ecotype. Thanks to use of essentially new type of homozygous lines there was the revision of value of early - ripening genotypes, allowing to extend current models of hybrids into production, also to change positively the economy of their growing and impact on the recognition and popularity early ripening hybrids, revolutionary change the assortment and structural composition for farms. 


\section{Bibliography}

1. Duvyk D.N. Recent achievements in the field of corn selection from the point of view increase of grain yield and quality / D.N. Duvyk // Production, processing, using of corn: International Symposium: Abstract of the papers. - Belgrade, 1980. - P. 4-6.

2. Rybalkin P.N. Heritage of Academician / P.N. Rybalkin // Genetics, selection and technology of corn growing. - Maikop: RYPO "Adygeia." - 1999. - P. 8-12.

3. Shpaar D. Maize. Growing, harvesting, conservation and utilization / D. Shpaar, K. Ginapp, D. Draeger, A. Zakharchenko etc. // Under the editorship D. Shpaara - Kyiv: Alpha stevia Ltd. 2009. - $396 \mathrm{p}$.

4. Stafer G.A. Physiological Bases of Maize Improvement: Should we bother? / G.A. Stafer, M.E. Otegue // Physiological Bases of Maize Improvement. - Buenos Aires, 1998. - P. 3-6.

5. Sozinov A.A. Genetics and progress of plant selection / A.A. Sozinov // Questions of selection and genetics of grain crops. - Moscow : CMEA, 1983. - P. 14-23.

6. Gudz Yu.V. Principles and methods of selection on the adaptability to irrigation conditions of South Steppe of Ukraine: Author's abstract of dissertation of Doctor of Agricultural Sciences / Yu.V. Gudz. Dnipropetrovsk, 1996. - 34 p.

7. Molchan I.M. Disputable issues in selection of plants / I.M. Molchan, L.G. llyina, P.I. Kubarev // Selection and Seed Production. - 1996. - No 1-2. - P. 36-51.

8. Farm producer from Virginia eclipsed the world record of grain yield with maize hybrid Pioneer $\AA$ P1197AM тм / Agroexpert - Journal of practical guide of farmers. - 25.12.2015. - Access mode: http://www.agroexpert.ua/detail/article/silgospvirobnik-z-virdzhiniji-pobiv-svitovii-rekord-z.html.

9. Basic aspects of the sustainability of grain production stability in the Steppe Zone of Ukraine / V.S. Rybka, M.S. Shevchenko, V.Yu. Cherchel [et al.] // Tavria Scientific Bulletin. - Kherson, 2013. - Vol. 85. P. 276-286.

10. Lakin G.F. Biometry: Textbook for biological specialities of high schools - 4 th ed., rev. and add. / G.F. Lakin - M .: High Scool.- 1990. - 352 p.

11. Atramentova L.O. Statistics for biologists: Textbook / L.A. Atramentova, O.M. Utyevska - Kharkiv .: Publishing house "NTMT", 2014. - $331 \mathrm{p}$.

12. Cherchel V.Yu. The strategy of domestic corn production in conditions of climate change / V.Yu. Cherchel // Propozition. Ukrainian magazine on agribusiness. - 2016. - No 7 / 8. - P. 69-73. 